\title{
'Н.К. Абдуллаев
}

1Әл-Фараби атындағы Қазақ ұлттық университеті, Қазақстан, Алматы қ. e-mail: nurzhan_kydyrali1985@mail.ru

\section{КӘАӘМ СӨЗІНІН ЭПИСТЕМОАОГИЯСЫ ЖӘНЕ КӘАӘМ ӘАІСТЕМЕСІНІН ҚААЫПТАСУЫ}

\begin{abstract}
Аңдатпа. Кәләм ілімінің алғашқы пайда болуында діни ұстанымдар аясында, діннің негізгі шарттарын қорғау көзделген. Бірақ, уақыт өте келе әр түрлі мәселелердің туындауымен кәләм ілімінің зерттеу ауқымы кеңейе түсті. Кәләм ілімінің тарихи бастауы хижри І-ғасырдың соңына қарай орын алады. Кәләм ілімі бастапқыда Муғтазиләмен қоса Нажжарилік, Кумләбилік, Кәррәмилік, Зәйдияік және Шииттердің Усули мазхабы секілді бағыттармен басталған. Кейіннен Матуридилік және Әшғарилікпен кәләм әдістемесі нық қалыптасып, жүйеленіп, бүгінге дейін жетті. Мақалада кәләм ілімінің пайда болуы, зерттеу тақырыбы мен мақсаттары және Ислам ғұламаларының кәләм іліміне берген түсініктемелері салыстырмалы түрде қарастырылды. Бұған қоса отандық ғалымдардың кәләм ілімі жайындағы мақалалары және шетелдік ғалымдардың да еңбектері зерделенді. Мақалада мұсылмандардың Грек философиясымен таныспай тұрған кезеңі, туындаған түрлі пікірлердің Ислам ғұламаларын тығырыққа тіреуі, белгілі бір әдістеме қалыптастыруда түрлі оқиғалардың белең алуы секілді маңызды мәселелер баяндалған. Исламның ойшы^дық тарихына қысқаша тоқталып, кәләм мен философия салалары бойынша еңбектер жазған әһли сүннет ғалымдары да сипатталып көрсетілді. Сондай-ақ "кәләм» сөзінің эпистемологиясы мен әдістемесінің қалыптасуы қаралып, жан-жақты зерттелді. Мақала жүйелеуде бірқатар тақырыпшаларға бөлінді.
\end{abstract}

Түйін сөздер: Кәләм, философия, мазхаб, матуриди, әшғари.

\author{
${ }^{1}$ N.K. Abdullayev \\ ${ }^{1}$ Al-Farabi Kazakh National University \\ Kazakhstan, Almaty, e-mail: nurzhan kydyrali1985@mail.ru
}

\section{Epistemology of the Word Kalam and the Formation of its Methodology}

Abstract. The initial aim of the foundation of science of kalam was to protect main principles of the religion. However, in the course of time kalam has become more widespread due to various issues. The beginning of the history of science of kalam dates back to the end of the $\mathrm{I}^{\text {th }}$ century of Hijri. Kalam as a discipline of Islamic knowledge was formed with the participation of such directions as the Mu'tazilah, Najjarites, Kuallabites, Karramites, Zeydites and Usuli madhhab of Shi'a. Later, with the participation of Maturidites and Asharites the science of kalam was established firmly. In this study, the research area and the purpose of science of kalam and explanations of Islamic scholars on science of kalam have been discussed in a comparative way. Moreover, studies of local and international scholars on science of kalam have also been researched. The article also discusses the period of Muslims prior to Greek philosophy, the time of uncertainty Islamic scholars encountered due to different opinions and problems during the establishment of methodology to deal with emerging issues. In addition, epistemology of the word "kalam" and the formation of its methodology has been studied thoroughly. The article was systematically divided into several subtopics.

Key words: Kalam, philosophy, madhhab, maturidi, ashari.

${ }^{1}$ Н.К. Абауммаев

'Казахский национальный университет имени аль-Фараби, Казахстан, г. Алматы e-mail: nurzhan_kydyrali1985@mail.ru

\section{Формирование методологии калам и эпистемология слова калам}

Аннотация. В начальный период формирования калам, ее основной целью было защита канонов религии в рамках религии. ОАнако, с течением времени в связи с возникновением различных вопросов ареал изучения учения калам нача^ расширятся. Начало истории формирования учения калам завершилось в конце 1-го века хиджры. Учение калам в начальный 
период сорормировывалась при участии таких направлении как мутазилиты, нажжариты, куалмабиты, каррамиты, зейдиты и шиитскими правовыми мазхабами. Позже в системном плане при участии матуридитов и ашаритов учение калам сформировалась и получила распространение до сегодняшнего времени. В Аанной статье в сравнительном виде описаны возникнование калам, ее предмет и цели, также и объяснения исламских ученых касательно учения калам. Наряду с этим, также изучены статьи отечественных ученых относительно учения калам и труды зарубежных ученых по данной тематике. Описаны направления и периоды до изучения мусульманами трудов греческой философии. При возникновении разных мнений у исламских ученых возникли затруднения, затронуты важные вопросы появившиеся на пути формирования определенной методологии. Вместе с этим, всесторонне изучены, рассмотрены эпистемология и методология формирования слова «калам». Аля систематизации, статья разделена на несколько тематик.

Кмючевые слова: Калам, философия, мазхаб, матуриди, ашари.

\section{Кіріспе}

Ислам діні келгенге дейін Араб өлкелерінде өздеріне тиесілі, жергілікті діни дәстүрлері бар еді. Бұл дәстүрлерінде олар рухани жаратылыстарды, әлемнің бастауы мен соңын Алламен тығыз қарастырды. Құдай мен әлем байланысы секілді көптеген түсініктері бар болатын. Аллаға сенетін бірақ оның жалғыз екенін қабылдамай, басқа да құдайлардың бар екеніне сенетін, Алла мен адамдар арасын байланыстырушы пұттарға иланатын. Бұл пұттар арқылы Аллаға қауышатынына сенетін, періштелер мен жындар секілді рухани жаратылыстардың Алламен туыстығы барын алға тартып, ақыретті жоққа шығаратын. Бұл көзқарастары жайында Кұран Кәрімде бірқатар аяттарда баяндалған (Мәйдә 5/76.,Нахл 16/73., Ахкәф 46/28., Зүмәр 39/3., Саффат37/57., Исра 17/40,98., Шуара 26/186., Ясин 36/78., Нәжм 53/27).

Исламның келуімен арабтардың сенімдері үлкен өзгеріске ұшырады дей аламыз. Бұл сенімдерді Кұран Кәрім кейбірін жоққа шығарса, кейбірін түзете дұрыстап, кейбіріне жаңа шарттармен қуаттай, бір сенім жүйесін қалыптастырды. Ислам да бұл сенім жүйесі «әмәнту» атпен белгілі.

Пайғамбардың дүниеден өтуімен, уахиді түсіндіру ісін кейінгі нәсіл сахабалар жалғастырды. Сахабалар өздерінің білімдері мен сол кездегі мәдени қалыптасқан ортасына қарай, қоғамға уахиді ашықтап түсіндіруге тырысты. Осылайша уахидің түсіндірілуінде пайғамбардан кейін «сахаба райы» немесе «сахаба көзқарасы» деген екінші ақылды қолдану кезеңі енді. Сахабалар Құран аяттарын дұрыс түсінуді және олардың түсу себептеріне негіздей уахиді интерпретациялау жүйесін қалыптастырды. Табиғин кезеңінде де бұл ұстаным жалғасты. Осылайша кейіңгі кезеңде Мекке мен Мәдина қалаларымен қоса Бағдат, Басра, Шам және Мысыр секілді мәдени ошақтардан атақты Ислам ғұламалары шыға бастады. Исламда ғалымдарды жетілдіруге aca көңіл бөлді деп айтуға болады. Бұның маңыздылығын Пайғамбардың хадисінен де көруге болады. Хадисте: «Алла хайыр қалаған адамды дінде ғалым (факих) етеді» (Бухари) делінген. Демек дінді құрушы Алла және оны адамдарға жеткізуші пайғамбар, оны түсіндіруде ақылды және білімді ұрпақтың жетілуін қалайтыны көрінуде.

Исламның Араб түбегінен әрі қарай асып таралуымен, ол жерлерден шыққан дін ғұламалары өмір сүрген аймақтарының әдет - ғұрпын, дәстүрлерін және қоғамдық көзқарастарын ескере отырып, Құран мен Сүннетке негіздеп, діни және моралдік тұрғыдағы үкімдерін салыстыра електен өткізіп қияс жасады. Сахаба көзқарасын жүйелендіре отыра «қияс» әдістемесін қалыптастырды.

Алғашқы кезде кәләмшылардың сүйенген кәләмдік қиясы, философия логикасына негізделген философиялық қиясқа жататын. Бірақ бұл жүйе ұзаққа бармады. Өйткені көбіне Аристотельдің логикасына негізделген философиялық қияс, кәләмдік қиястың орнын басқан болатын. Бұның нәтижесінде ақылдың дұрыс көрген үкімдері қабылданып, ақылдың бұрыс көрген үкімдерінен бас тарту секілді жүйе қалыптасты. Бұл әдісті ең көп қолданған Мұғтазилә бағыты болатын. Олар көбіне қарсыластарына жауап беру мақсатында, философиялық әдіске көп жүгінетін. Осылайша философияны үйрене, логикадан пайдалана отырып, «жәдәл» (мәшһүр болган немесе туралыгында мүбә болмаган, барлыгы тарапьнан дұрыс деп багаланып және оган сүйенетін құяс. Тартыста құрсыласын сөйлетпеу немесе аузын аштылмма магынасында құолданылатын логика, философия және кәләм термині больп табылады. Әрине «жәдәл» агылшын тіліндегі «диалектика» сөзінің баламасы. Ислам вұла- 
малары «жәдәл» сөзіне түрлі анықтамалар беруде. Бірақ философия мен кәләмдавы жәдәл сөзінің ең мәшһүр анықтамасы: белгілі бір пікірдегі карама қ̧айшыльқттарды тарmыса отырып талқылау өнері.) әдістемесін қалыптастырды.

Кәләм ілімі Ислам заңдылығының аясында болуымен философиядан бөлінеді. Философия да кәләм ғылымы сияқты Алланың заты мен сипаттары, жаратылыстың бастауы мен соңы тұрғысындағы тақырыптарды қарастырады (Улви Мурат Клавуз 2013)[1; 12 б.]. Бірақ бұл тақырыптарды зерттеуде ақылды негізге алады. Ақылға келмейтін тақырыптарда нақылға (аят және хадис) дәлел ретінде сүйенбейді. Кәләмның алғашқы сүйенетіні уахи болып табылады. Кәләм, сенім тақырыптарын түсіндіруде және анықтау кезінде ақылға орын берсе де, негізгі дәлелі уахи болып, Ислам принциптерінен алшақ кетпейді. Кәләмның бұл тұсы, нақты ақылға жүгінген және уахиді қабыл етпейтін философиядан бөлінеді.

Әрине, Аристотель логикасының философиялық қияс болып Ислам әлеміне енуінен кейін кәләмшылардың негізгі әдістемесіне айналады. Бұл әдістемеге қарсы көптеген көзқарастар ұсынылса да еш нәтиже бермеді. Ислам ғалымдарының алдында бұл әдістемені жаңарту жобасы тұрды. Бұл әдістемені өзгертіп және түзеткен алғашында Мұғтазила болып, кейін Әһли сүннет толықтай бір жүйеге келтірді [2; 21 б.].

\section{«Кәләм» сөзі}

Сөздің көпше түрін білдіретін кәләм сөзі - «әсер ету, жаралау» мағыналарын білдіретін «кәлм» түбірінен шыққан, «бір нақты көзқарасты білдіретін сөз» дегенді білдіреді.

Кәләм ілімінің Ислам тарихында алғаш кездесуі әһли сүннет мектебіне қарсы топтар арасында пайда болды. Сүнниттік мектеп бұларды бидғатшылықпен айыптады. Әһли сүннет сенім тақырыптарындағы көзқарастарының жинақталуы (тәдуин) кезеңінде, өз еңбектеріне «кәләм ілімі» атауын бермей, оның орнына «әлФикһу л-Әкбәр» атауын беруді жөн көрген. Осы себепті де Әбу Ханифаның еңбегіне берілген аты секілді. Бастапқы кезеңде Сүнниттік мектептің өкілдері кәләм ілімімен айналысқандарға қарсы шықса да, кейіннен сүнниттік медреселер кәләм ілімімен айналысуды бидғат емес, керісінше әһли сүннет ақидасын қорғау әрі сақтау үшін керекті деді. Әрі мұсылмандардың көңілдеріндегі күмәндерді кетіріп, сейілту мақсатында маңызды екенін баяндады (Бекир Топалоглу ауд. 2011)[3; 190 б.].
Кәләм ілімінің тақырыбына, мақсатына және мектептеріне қарай әр түрлі түсініктеме беруге болады. Тақырыбына қарай берілген түсініктемеде Алладан басқа пайғамбарлықты, әрі ақыретті де қоса қарастырған. Ал кейбір кәләмшылар иманның үш негізгі шарттарын да қамтыған. Оларды атап айтар болсақ, «Алланың заты және сипаттары, пайғамбарлық тақырыптары, әлем жаратылысының бастауы мен соңындағы мәселелерді Ислам заңдылығы негізінде қозғайтын ілім» ретінде танытады.

Кәләм ілімінің «кәләм» - деп аталуының себебі жайында бірнеше көзқарас бар.

Біріншісі: Кәләмға қатысты еңбектерде көбіне мынадай ұғымдар қолданылуда: «әлкәләм фи-л ираде» (қалау жайындағы сөз), «әл-кәләм фи-л әрзәқ» (ризық жайындағы сөз). Осы секілді сөйлемдердің көп кездесуінің нәтижесінде «кәләм» деп аталуы.

Екіншісі: кәләм ілімінде ең көп талқыланып тартысқа түскен тақырыптардан бірі «кәләмулла» (Алланың кәләм сипаты) мәселесінен шығуда делінеді.

Үшіншісі: кәләмның жәдәл және диалектикада ең ыңғайлы ғылым саласы ретінде білінуде. Бір мәселе жайында тартыста көбіне сөзге мұқтаждық туындайды, осы себебпті де кәләм деген атау берілген. (Kilavuz 2016) [4].

Кәләмның мақсатына түсіндіруде Әбу Наср әл-Фараби мен Адудуддин әл-Ижидің берген анықтамасы ерекше. Ол: «Кәләм өнері дінді құрушының ашықтап түсініктеме берген белгілі көзқарасын және қарым-қатынасын көрсетіп, бұл көзқарасқа қарсы болған әрбір нәрсенің қате екенін сөзбен айқындап білдіретін талқылау әдісі» -деп келтірген. Әл-Фараби анықтамасында кәләм ілімінің құрамына тек сенім мәселелерін емес, қарымқатынастарды да бірге қамтып діннің негізгі аумағына енгізген. Кәләм ілімін дінді қорғау мақсатында пайда болған сала ретінде көрсеткен.

Адудуддин әл- Ижи де әл-Фарабиге ұқсас анықтама келтірген: «Кәләм - нақты дәләлдер келтіру және қарсы көзқарастарды жоққа шығарып әшкерелеп, діни сенімді дәлелдеп, оны ғылыми куаттайтын ғылым» (Y. S. Yavuz.) [5] -деп белгілеген.

Шахристани (д.ө.548/1153) кәләм іліміне берген түсіндірмесінде, дінді екіге бөліп қарастырады: Біріншісі мағрифат (Алланы және одан келгендерді білу), екіншісі тағат (ғибадат). Кімде кім мағрифат, тәухид тақырыптарымен айналысатын болса, ол адам усулші (бұл жерде сенім мәселелерімен айналысқан адамды мең- 
зеуде), ал кімде кім тағат, ғибадат және құлшылық тақырыптарымен айналысатын болса, ол адам фуруғшы болатынын айтуда. Усул, кәләм ілімінің тақырыптарына жатса, фуруғ фиқһ ілімінің тақырыптарына кіруде (Shahristani 1975) [6; 51 б.].

Тақырыбына және мақсатына қарай берілген түсіндірмелер бойынша кәләм ілімі белгілі бір мектепке тиесілі емес, керісінше барлық кәләм мектептерін қарастыратын бір сала ретінде анықталады. Бірақ Имам Ғазали кәләмды Әһли - сүннет сенімін қорғаушы және әһли -бидғат алға тартқан сындарға жауап беретін бір ғылым деп түсіндірген. Әрі діннің негізгі шарттары мен ақылдың принциптерін байланыстыру Әһлисүннеттің жеткен жетістігі екенін білдіреді. Хашуия және Муғтазилә секілді астамшылыққа кеткен бағыттардың бұл функцияны атқара алмағандығын жеткізеді [5].

\section{Кәләм әдістемесі}

Ислам әлемі Грек философиясына дейін Құран, Сүннет, арабша граматика, шешендік өнер, риторика, фольклор т.б., мәдени құндылықтарға ие еді. Олардың ойлануы, сөйлеуі және адамдармен байланыс құруы осы құндылықтардың аясында іске асатын. Құран кәрімдегі ақылға салыңдар, ойланыңдар деген бұйрыққа сай олар талаптарының үдесінен шығуға тырысты.

Әмәуилер кезеңінде Ислам кең тарап, жаңа барған жерлерде саяси қиындықтар, түсініспеушіліктер орын алды. Өйткені Исламның жаңа барған жерлерінде өмір сүрген Христиан, Иудаизм және Мәжуси өкілдері бар болатын . Бұлардың көбісі исламды қабылдаса да, ескі діндерінің және қалыптасқан мәдениетінің ықпалынан шыға алмағандары көрінеді. Исламды түсіндіруде осы секілді қиыншылықтар кездесіп отырды. Кейінен тағдыр, Құранның жаратылуы, Алланың сипаттары, Алланың көрінуі тұрғысындағы тақырыптар талқылана бастады. Осы кезеңде туындаған мәселелерге Мұғтазиланың қолданған әдістемесін басқа да мұсылмандардың қолдануын ұсынды. Осы арқылы мұсылмандардың іштеріндегі күмәнді сейілтеді деген үміт болды.

Аббасилер кезеңінде Ислам әлеміне герметизм және политеизм ұстанушылары қауіптің бір көзі деп танылды. Біріншісі көне мәдениеттен, грек философиясынан сусындаған болса, екіншісі тұнып тұрған Мәжусиліктің көрінісі еді. Бұлардың арасында Манихилік өкілдері де кездесетін. Сонымен қоса, көбі философияны жақсы меңгерген еді. Аббаси халифалары бұл қауіптің алдын алу мақсатында
Мұғтазила өкілдеріне үлкен көмек көрсетті. Аббаси халифасы Мансур кезеңінде Гректердің философия кітаптары арабшаға түсіндірмелерімен аударылды. Мансурдан кейін баласы Мәһдидің халифалыққа келуімен политеизм өкілдерін куғындады. Бұл шаралар өзінен кейін Хади, Харун Рашид және Әмин кезеңдерінде де өз мәресінде болды. Хижри 198 жылы Мәмунның халифалыққа келуімен алдыңғы қауіп сейілген еді. Бұл кезеңде философия кітаптарымен қоса геометрия, арифметика және медицинаға байланысты көптеген еңбектер араб тіліне аударылды. (Челеби 2005) [7].

Аббасилер гностицизм мен герметизмге төтеп беру үшін грек философиясы мен логикасын кең пайдалана түсті. Бұл жолдың тереңдей түсуінен қауіптенген сүннетке сүйенген Әһли сүннет кәләмшылары, бұның Ислам мәдениетіне кері әсер ететінін алдыға тартқан. Осылайша бұл жолдың арасынан орта жол іздеуге кіріседі. Әрине, бұл жолдағылардың басында Әбу Мансур әл-Матуриди және Әбу -л - Хасан Әл-Әшғари келуде. Бұл көрнекті екі ғалымның Ислам әлеміне тигізген еңбегі зор. Олар Әһли сүннет кәләмшыларының Құран мен сүннет аясында ой түзуін бір жүйеге келтірді.

Ислам да нақыл мен ақылдың өлшемін анықтағандардың бірі Имам Ғазали еді. Ғазалидің уақытында герметизм, гностицизм және философияның даңқы шарықтап тұрды. Дәл осы уақытта діннің жағдайы, пайғамбарлықты және мұғжизаларды жоққа шығарған философтардың және барлық жаратылғанға сенуге итермелейтін герметиктердің доктриналары діннің алдындағы үлкен қауіп деп есептелді. Ғазали - Грек логикасынан, герметизмнен және басқа да ғылым салаларын терең меңгерген және кәләмшыларды қыспаққа алған философтарға қарсы, діннің жалпы ойлау кеңістігін дамыта отырып, бұл туындаған мәселелерге алғашқы тұшымды жауап берген ғалымдардың бірі. Ол өзінің «Мақ̧асиду-л Фәләсифа» еңбегінде философиядан алыну керек болған және бас тарту керек болған мәселелерді қозғайды. Кейіннен философтардың көзқарастарынан қабылданбайтын мәселелерді сынай отырып «Тәһәфуту-л Фәләсифә» еңбегін жазады.

Сахабалардан Ғазалиге дейінгі кезеңде Ислам әлемі әртүрлі мәселелермен бетпе-бет келгендігін көрудеміз. Бірақ Ислам ғұламалары алғашқы сәләф ғалымдарының сызған шеңберінен шықпағандығын, түрлі қиындықтарда түрлі шешімдер мен әдістемелерді тапқандығына да ислам тарихынан куә болудамыз. 
Сунниттік кәләм мектебінің белгілі өкілдерінің бірі Әбул Муин ән-Нәсәфидің (д.ө. 508/1115) еңбектерінде Матуридидің тарихы және белгілі ғалымдары жайында білдіреді. Матуридилік мектептің қолданған әдістемесін жүйелендіре әрі қарай дамытты (Y. S. Yavuz.) [8]. Кәләм ілімінің алғашқы мутақаддимин ғұламалары кезеңінде, ақиқатты анықтау жолында, аса маңызды жүйелі әдістемелер қалыптастырды.

Әшғари кәләм мектебінің көрнекті ғалымдарының бірі Жувайни (д.ө.478/1085) діндегі ақылдың орнын белгілей, Құран және хадистерде келтірілген мутәшәббих аяттарға тәуил жасаған ғалымдардан. Жувейни кезеңімен алғашқы мутақаддимин дәуірі бітіп, шәкірті Ғазалимен кейінгі мутәаххирин кезеңі басталады [2].

Ғазалидің кезеңінде Исламда логикаға ерекше мән берілді. Әрі бидғат деп танылған жаңа ағымдар мен философтарға қарсы сенім мәселелерін қорғау мақсатында еңбектер жазды. Ғазали логиканы (мантық) бір құрал ретінде қабылдап, оны білу әрі меңгеру әрбір ғалымға міндетті-дей келе, логиканы білмеген адамның білімі сенімсіздік тудыратынын айтқан. Ғазали өз кезеңіндегі түрлі бағыттарды сынай отырып, Ислам принциптерінің қағидаларының аясында жауап берген ғұламалар санатынан болып табылады.

\section{Қорытынды}

Исламдағы ойшылдық тарихына көз жүгіртер болсақ, кәләм мен философияны бір арнаға тоғыстыру турасында ғұламалардың атқарғарған еңбектері аз емес. Ғазалиден кейін де Ибн Рушд, Рази және тағы да басқа ғұламаладың бұл жолда еңбектержазып тер төккендігікөрінуде. Тарих бойынша кәләм әдістемесінің қалыптасуы қоғамдағы туындаған мәселелерді шешу жолында әртүрлі кезендерді басынан өткізді. Кейінгі кезеңдерде өз топтарында болмағандарды діннің шеңберінен шығарып, өз топтарын діннің шеңбері деп сенетін түрлі бағыттар қалыптасты. Әр бағыттағылар өз имамының ижтихадтарын, шығарған үкімдерін мәжбүрлі сенім ретінде қабылдай бастады. Жаңа туындаған мәселелерге шешімдер шығарылмады. Бұдан аттағандарға бидғат, адасушылық деген айып тағылып, динамикалық дін түсінігі статикалық түрге енді. Бүгінгі күннің мәселелерін шешуде, қоғамда туындаған сұрақтарға жауап беру үшін, классикалық кәләм түсінігін жаңарту бүгінгі күннің талабының бірі ретінде көрінуде. Жаңа әдістемелерге көшуден бұрын, классикалық еңбектердің де зерттеліп зерделенгені жөн. Бүгінгі күні Қазақстан Республикасы аумағында кәләм ғылымы қолға алынған. Қазақ даласынан шыққан белгілі кәләм ғұламаларының еңбектері зерттелу үстінде.

\section{Әдебиеттер}

Ulvi Murat, Ahmet Saim, Kelama Girirs, - Istanbul. - 2013. 209 - б.

Топалоғлу Б. Ислам теологиясы. Кіріспе: Окулық/Ауд. Н.Ж.Байтенова, С.У.Абжалов. - Алматы. 2014. - 276 б.

Muhammed b. Tavit et-Tanzhi. Kelam Ilmi. Terc.:Bekir Topaloglu. Mezhepler Arastirmalari, IV/1. - 2011. 290 - б.

Kilavuz, Ahmet Saim. Ana Hatlariyla Islam Akaidi ve Kelama Giris. Istanbul: Ensar yay., 2016. 496s.

Yavuz, Yusuf Sefki. «Kelam» md.» «Ислам Энииклопедиясы» / DIA,

Shahristani. Milel ve Nihal. Beyrut, 1975. 510 - б.

Celebi Ilyas, «Kelam Metodunun Ortaya Çıkışı Gelişim Süreci ve Yeni Metot Arayışları»/makale, Istanbul. - 2005.

Yavuz, Yusuf Sevki. «Nesefi,Ebu-1 Muin» md. «ИсламЭничиклопедиясы» / DIA.

\section{References}

Ulvi Murat, Ahmet Saim, Kelama Girirs, - Istanbul. - 2013. 209 - b.

Topaloғlu B. Islam teologiyasy. Kirispe: Оқиlук/Aud. N.ZH.Bajtenova, S.U.Abzhalov. - Almaty. 2014. - 276 b. Muhammed b. Tavit et-Tanzhi. Kelam Ilmi. Terc.:Bekir Topaloglu. Mezhepler Arastirmalari, IV/1. - 2011. 290 - b. Kilavuz, Ahmet Saim. Ana Hatlariyla Islam Akaidi ve Kelama Giris. Istanbul: Ensar yay., 2016. 496s.

Yavuz, Yusuf Sefki. «Kelam» md.» «Islam Enciklopediyasy» / DIA,

Shahristani. Milel ve Nihal. Beyrut, 1975. 510 - b.

Celebi Ilyas, «Kelam Metodunun Ortaya Çıkışı Gelişim Süreci ve Yeni Metot Arayışları»/makale, Istanbul. - 2005.

Yavuz, Yusuf Sevki. «Nesefi, Ebu-1 Muin» md. «IslamEnciklopediyasy» / DIA. 